\title{
Effect of Balneotherapy on Chronic Low Back Pain at Hot Springs in Southern Ethiopia: Perceived Improvements from Pain
}

\author{
Yusuf Haji (D) \\ Fiker Taddesse ${ }^{2}$ \\ Simegn Serka ${ }^{3}$ \\ Achamyelesh Gebretsadik' \\ 'Hawassa University, College of Medicine \\ and Health Science, School of Public \\ Health, Hawassa, Ethiopia; ${ }^{2}$ Hawassa \\ University, College of Medicine and \\ Health Science, School of Medicine, \\ Hawassa, Ethiopia; ${ }^{3}$ Hawassa University, \\ College of Natural and Computational \\ Science, Department of Chemistry, \\ Hawassa, Ethiopia
}

Background: Low back pain (LBP) is an important musculoskeletal condition results in clinical, social and public health problems globally. Hydrotherapy, using water and heat together can be utilized to treat conditions, relieve pain and increase muscular power and a range of joint movement in patients with chronic lower back pain. Most patients with acute LBP improve spontaneously within four weeks; however, chronic LBP is extremely common and usually mechanical in nature.

Objective: The objective of the current study was to assess effect of balneotherapy in decreasing the lower back pain and its improvements among adults using a spa in southern Ethiopia.

Methods: We employed a single arm cohort study and convenient sampling method to select 442 study participants from four hot springs located in Sidama Region and Gedeo Zone, Southern Ethiopia. Structured and pretested questionnaire was used and administered face-to-face by trained data collectors. Data were entered using EpiData and transferred to SPSS for cleaning and analysis. Descriptive and bivariate analyses were made.

Results: A total of 427 participants were included in the study giving response rate of $96.6 \%$. The mean (standard deviation) age of respondents was $42.55( \pm 14.92)$ years. Perceived improvement from back pain was 332 (77.8\%) with 95\% confidence interval (CI) of $74-82 \%$. Factors showing association with perceived improvement from back pain after spa therapy were, study site being near Hawassa (Burkitu) with crude odds ratio (COR) of 3.3 and $95 \% \mathrm{CI}: 1.83-5.98$ and $p$-value $<0.001$; and sex of respondents that the odds of perceived improvements among males were about twofold compared with females, (COR: 1.7, 95\%CI: $1.07-2.74, p$-value 0.025 .

Conclusion: Our study shows significant perceived improvement from back pain after utilization of spa water. This is associated with type of hot spring used, male sex, and having neurological symptoms. Therefore, hot spring spa water had better therapeutic effect for back pain and emphasis should be given to integrate it with modern medicine and further experimental study to be conducted to recommend it for medical purposes.

Keywords: balneotherapy, chronic back pain, hot springs, Southern Ethiopia

\section{Introduction}

Musculoskeletal conditions, also called musculoskeletal disorders, consist of conditions where a part of the musculoskeletal system is injured or affected over time. Symptoms include pain, dysfunction or discomfort in the bones, joints, muscles, or surrounding structures, which can be acute or chronic, focal, or diffuse. The most frequent musculoskeletal disorders are osteoarthritis, fibromyalgia, rheumatoid arthritis, and low back pain (LBP). ${ }^{1}$
Correspondence: Yusuf Haji

School of Public Health, College of

Medicine and Health Science, Hawassa

University, Hawassa, Ethiopia

Email yusufahaji438@gmail.com 
LBP is pain, muscle tension, or stiffness localized below the costal margin and above the inferior gluteal lines, with or without sciatica or nerve pain and defined as chronic when it lasts for 12 weeks or more. ${ }^{2}$ LBP is an important musculoskeletal condition that results in clinical, social and public health problems globally. ${ }^{3}$ It is the most common musculoskeletal complaint with lifetime incidence estimated at $80 \%$ and it is also a main cause of loss of work and has significant effects on the economy. Most patients with acute LBP improve spontaneously within four weeks; however, chronic LBP is extremely common and usually mechanical in nature. ${ }^{4}$ Attributing symptoms of low back pain to a specific disease or spinal pathology is a challenge. ${ }^{5}$ Spinal imaging abnormalities, such as degenerative disc disease, facet joint arthropathy, and bulging or herniated intervertebral discs, are extremely common in patients with or without low back pain, particularly in older adults, and such findings are poor predictors for the presence or severity of low back pain. ${ }^{6}$

The treatment for LBP includes pharmacological and nonpharmacological therapies. And, BT is one of the nonpharmacological therapies in thermal ground water. Ground water having minerals of the World Health Organization's (WHO) drinking water standards and a temperature of above $40^{\circ} \mathrm{C}$ is considered as hot mineral spring water. The benefit of bathing in mineral spring water comes from the mineral contents and the temperature. ${ }^{7}$ Hot water springs (mineral and geothermal waters) are found all over the world at special geographical areas. ${ }^{8}$ The nature of the water in hot spring is usually alkaline, having acidic properties in some areas. The alkalinity of hot water springs is mainly the result of potassium, calcium, magnesium, and sodium ions. ${ }^{7}$ Moreover, the chemical component of the water changes according to the chemical constituent of the rocks over which the water flows.

The term balneotherapy (BT) (seated immersion or spatherapy) is classically used in (Eastern) European countries for bathing in water without exercise. Often, natural mineral or thermal waters are used for bathing, drinking, and inhalation. ${ }^{9} \mathrm{BT}$ is the use of mineral water for the treatment of wide range of diseases such as atopic dermatitis, psoriasis, rheumatoid arthritis (RA), ankylosing spondylitis, osteoarthritis, and LBP and has been practiced for a long time around the world. ${ }^{10,11}$ People usually use it to get relief from such pain, and studies show that improvement is often seen in the subacute phase between four and 12 weeks, although at a slower rate than observed at first. ${ }^{12}$
Other studies conducted in patients with osteoarthritis of the hip, knee, or lumbar spine also showed satisfactory results obtained with $\mathrm{BT}^{13-16}$ In addition, a study to evaluate the importance of bathing in bicarbonate or baking soda water showed its help in the opening of peripheral blood vessels, and immune regulation in the skin respectively. ${ }^{17}$ For example, a trial conducted among patients with chronic lower back pain (CLBP) through use of spa therapy reported that it is beneficial for CLBP and proved to induce changes in proteins involved in functions such as gene expression modulation, differentiation, angiogenesis, tissue repair, acute and chronic inflammatory response. ${ }^{18}$ According to trial studies in Turkey and Bulgaria on combination therapy of BT, there was increased effectiveness of the treatment. ${ }^{19,20}$ Another study in Antsirabe, Madagascar, on water analysis and its application shows that BT is utilized in order to treat different pathologies, mainly musculoskeletal disorders, using different types of mineral waters, which are characterized by curative properties. ${ }^{21}$ Moreover, a systematic review and meta-analysis on effectiveness of spa therapy for patients with LBP confirmed that spa therapy can benefit, relieving pain and improving lumbar spine function among these patients. ${ }^{22}$

Different methods can be applied for treatment and management of CLBP, including pharmacological and nonpharmacological treatments. ${ }^{18}$ A systematic review and meta-analysis demonstrated that spa therapy may have short-term beneficial effects on pain relief and lumbar spine mobility improvement in patients with CLBP. ${ }^{14}$ Spa therapy is a nonpharmacological and widely used treatment, ${ }^{19}$ in which patients bathe in natural spring water with a temperature over $20^{\circ} \mathrm{C}$ and rich mineral contents for 20 to $30 \mathrm{~min}$.

On immersion in spa water a fall in hemoglobin concentration, packed cell volume, red cell count, and albumin concentration was observed and also if the depth and temperature of the water are the same, the renal, hematological, and cardiac changes of immersion occur to the same degree in both media. ${ }^{23}$

These days, when warm water is readily obtained from springs in every country, the question arises of whether this warm mineral water is of any medical importance. For this reason, physicochemical analyses are the first step in order to discover these characteristics. ${ }^{21}$ Hydrotherapy, using water and heat together to treat conditions, relieve pain and increase muscular power and a range of joint movement, has been a mainstay of managing many 
medical conditions. These include arthritis, neurological conditions, and rehabilitation from sports injuries. ${ }^{21}$

Nowadays, clinicians make decisions about therapy using the available evidence known as evidence-based medicine (EBM). The evidence-based approach represents a return to the empirical process of gathering information and is a step away from or beyond the rational approach to choosing therapy that has been used in medical practice. Therefore, balneotherapy can be considered as one of the measures to decrease adverse drug reactions and the purpose of the current study was, therefore, to assess the effect of spa therapy in patients with chronic low back pain using BT in selected hot springs of southern Ethiopia.

\section{Materials and Methods Study Site and Period}

The study was conducted in Berisso (Dilla woreda), Yirgalem (Yirgalem town), Burkitu (Hawassa city) and Shebele (Wondo woreda) hot water springs in Southern Ethiopia, from June 3-July 30, 2019. For this reason, physicochemical analyses were the first step in order to discover these characteristics as shown in Table 1. The hot springs were selected by their therapeutic composition of elements and ions. These hot springs were located in the Great Rift Valley of East Africa where more than 120 hot springs are located.

\section{Source and Study Population}

The source population was all BT users at the hot springs found in the Southern region during the study period. While the study population was those adults with LBP aged 18 years or more who were using BT at the selected hot springs in the study area during the study period.

\section{Study Design}

We conducted a single arm cohort study to observe patients' improvement from their complaint after utilization of the spa for at least three days.

\section{Sample Size Determination}

The sample size for the study was determined using a single population proportion formula for the study objective. To our best knowledge there was no study conducted in these important areas and therefore, a maximum sample

Table I Physicochemical Qualities of Studied Hot Springs Water in SNNPR, 20I9

\begin{tabular}{|c|c|c|c|c|c|c|}
\hline Parameters & Yirgalem (Yirgalem) & Shebele (Wondogenet) & Barsiso (Dilla) & Burkitu (Hawassa) & WHO & Unit \\
\hline $\mathrm{pH}$ & 7.9 & 8.3 & 7.56 & 6.9 & $(6.5-8.5) \mathrm{a}$ & \\
\hline Temperature & 42.8 & 60.2 & 51.4 & 60.2 & $35 c$ & $0 c$ \\
\hline Conductivity & 292 & 665 & 2835 & 1266 & $(I 80-600) b$ & $\mu \mathrm{s} / \mathrm{cm}$ \\
\hline TDS & 146 & 333 & $14 \mid 7.5$ & 633 & $1200 \mathrm{~b}$ & $\mathrm{mg} / \mathrm{L}$ \\
\hline Turbidity & 0.0 & 0.0 & 3.00 & 0.0 & $5 \mathrm{~b}$ & NTU \\
\hline Total chlorine & 0.04 & 0.0 & 0.08 & 0.02 & $5 b$ & $\mathrm{mg} / \mathrm{L}$ \\
\hline Total hardness & 45 & 60 & 40 & 70 & $300 c$ & $\mathrm{mg} / \mathrm{L}$ \\
\hline Calcium hardness & 25 & 30 & 30 & 50 & & $\mathrm{mg} / \mathrm{L}$ \\
\hline Magnesium hardness & 20 & 30 & 10 & 20 & & $\mathrm{mg} / \mathrm{L}$ \\
\hline Total alkalinity & 150 & 300 & 1200 & 600 & $200 b$ & $\mathrm{mg} / \mathrm{L}$ \\
\hline Bicarbonate alkalinity & 150 & 300 & 1200 & 600 & - & $\mathrm{mg} / \mathrm{L}$ \\
\hline Dissolved $\mathrm{NH}_{3}$ & 0.00 & 0.45 & 0.33 & 0.46 & $1.5 b$ & $\mathrm{mg} / \mathrm{L}$ \\
\hline $\mathrm{NH}_{4}+$ ammonium & 0.00 & 0.58 & 0.35 & 0.60 & $1.5 \mathrm{~b}$ & $\mathrm{mg} / \mathrm{L}$ \\
\hline $\mathrm{Na}+$ sodium & 50.7 & 86.2 & 587.3 & 258.6 & $200 b$ & $\mathrm{mg} / \mathrm{L}$ \\
\hline $\mathrm{K}+$ potassium & 6.6 & 48.0 & 12 & 39.0 & $1.5 b$ & $\mathrm{mg} / \mathrm{L}$ \\
\hline $\mathrm{Ca}+$ calcium & 10.0 & 12.0 & 12 & 20.0 & $75 b$ & $\mathrm{mg} / \mathrm{L}$ \\
\hline Mg+ magnesium & 4.9 & 7.3 & 2.4 & 4.9 & $50 b$ & $\mathrm{mg} / \mathrm{L}$ \\
\hline $\mathrm{Cl}$ - chloride & 1.3 & 3.0 & 1.3 & 1.3 & $250 b$ & $\mathrm{mg} / \mathrm{L}$ \\
\hline F- fluoride & 1.74 & 0.91 & 8.12 & 5.73 & $1.5 b$ & $\mathrm{mg} / \mathrm{L}$ \\
\hline $\mathrm{NO}_{2}^{-}$nitrite & 0.02 & 0.03 & 0.03 & 0.05 & $3 b$ & $\mathrm{mg} / \mathrm{L}$ \\
\hline $\mathrm{NO}_{3}{ }^{-}$nitrate & 9.2 & 2.2 & 14.5 & 6.6 & $50 \mathrm{~b}$ & $\mathrm{mg} / \mathrm{L}$ \\
\hline $\mathrm{SO}_{4}{ }^{2-}$ sulphate & 1.0 & I & 80 & 61 & $400 a$ & $\mathrm{mg} / \mathrm{L}$ \\
\hline $\mathrm{PO}_{4}{ }^{3-}$ phosphate & 0.30 & 1.22 & 4.8 & 0.39 & - & $\mathrm{mg} / \mathrm{L}$ \\
\hline $\mathrm{HCO}_{3-}$ bicarbonate & 183 & 366 & 1464 & 732 & - & \\
\hline
\end{tabular}


size (assumed level of improvement from CLBP disorders of $50 \%$ ) formula was employed.

These are the assumptions: type I error $(\alpha)$ probability of $5 \%$ (two-tailed test); $95 \%$ confidence level; $p 0.5$ (proportion of improvement from pain); d (precision) $5 \%$.

The sample size was 384 . After considering $15 \%$ nonresponses and refusals, the total sample size required for the study was 442 persons.

\section{Sampling Procedures}

We used convenient sampling to include study subjects. This was considering the accessibility of the participants and time constraints. We had proportionally allocated study subjects to the four selected hot springs based on the client flow and availability of interested health problems. An average of 110 samples was allocated at each of the four sites. We had included patients aged 18 years or above with back pain until the required 442 sample size fulfilled. The diagnosis was made by health professionals based on their complaint.

\section{Inclusion/Exclusion Criteria Inclusion}

We have included those clients with LBP persisting for 12 weeks and who were using the hot spring for healthrelated problem improvements and wanted to stay for at least three days or had already stayed three or more days at the start of interview to follow the change in symptoms (improvement from pain).

\section{Exclusion}

Cases other than back pain were excluded and those clients there for recreational purposes were also excluded. We have also excluded severely ill patients, those who were unwilling to participate and those who were unable to communicate from the study.

\section{Variables}

Dependent: improvement from sign/symptoms of LBP

Independent: sociodemographic factors, duration of illness, type of illness, type of hot springs (with their physicochemical properties)

\section{Data Collection and Tools}

Since musculoskeletal diseases are the most common conditions that are treated by hot springs internationally, a questionnaire that includes the signs, symptoms and laboratory investigations needed to diagnose these specific diseases with sociodemographic characteristics of the respondents was developed. The tool was pretested on $5 \%$ of the respondents from another hot spring (Alaba site) and then we modified it as needed. The selection of sites for the study was convenient considering the hot springs being used for balneotherapy. Proportional allocation of the sample to the study sites was used based on the client flow to collect the data over an eight-week period by deploying three data collectors and one supervisor for each target site. The recruitment of the data collection team was based on educational status (at least degree holders in health-related fields), and proficiency in the local languages, Sidamu Afo and Amharic. Prior to the data collection, two days training was provided for data collectors and supervisors.

\section{Physical Examination (Diagnosis for LBP)}

We made diagnosis of LBP based on medical history and physical exam. During the exam, a health-care provider asked about the onset, site, and severity of the pain; duration of symptoms and any limitations in movement; and history of previous episodes or any health conditions that might be related to the pain. Along with a thorough back examination, neurologic tests were conducted to determine the cause of pain and appropriate treatment. To classify the LBP as chronic, a pain duration of $>12$ weeks was considered. ${ }^{24}$

\section{Analysis of Physicochemical Properties of Studied Hot Springs}

The data collection procedures followed the recommendations of the Standard Methods for the Examination of Water and Sediments Manual of the American Public Health Association ${ }^{25}$ for sample container preparation, storage and transportation. Samples of water were collected from different points of the selected hot springs following the standard sampling guidelines and methods set by the World Health Organization ${ }^{26}$ and then analyzed according to procedures specified by APHA. ${ }^{25}$

\section{Data Analysis}

The data were entered using EpiData software version 3.1 and transferred to SPSS software version 25 for analyses. Data cleaning, recording and analysis were made using SPSS. Descriptive statistics were used to present sociodemographic and univariate results of BT use in patients using the spa and the data were coded by identifying those symptoms improved/not improved by balneotherapy and by considering 
the time factor. Finally, binary logistic regression analysis with $95 \% \mathrm{CI}$ was used to examine the association between improvement/nonimprovement and hot springs having comparable elements and ions suitable for BT.

\section{Operational Definitions}

Low back pain is a posterior trunk pain between the ribcage and the gluteal folds. It also includes lower extremity pain that results from low back disorder. It can be acute LBP when the pain lasts $<6$ weeks duration; subacute when the pain lasts $>6$ weeks but $<12$ weeks duration, and called chronic LBP when the pain disabling the patient from life activities lasts $>12$ weeks. ${ }^{27}$

Balneotherapy (bathing in water) is a type of therapy that aims to reduce pain and improve daily functioning. Balneotherapy often takes place at centers with thermal baths or seawater baths.

Balneology is the scientific study of the therapeutic benefits of naturally occurring mineral waters. Throughout Europe and Japan, balneology and hot spring therapy has been incorporated within routine medical care treatments. Licensed doctors have now come to recognize the value of prescribing bathing in mineral waters as part of a preventative approach to illness.

\section{Results}

\section{Sociodemographic Characteristics}

A total of 442 selected participants, 427 of whom had back pain were included in the study, making a response rate of $97 \%$. These patients were from four hot springs included in the study namely, Barsiso (Dilla)-145 (34\%), Shebele (Wondogenet)-166 (27.2\%), Burkitu (Hawassa) 86 (20.1\%) and Yirgalem-80 (18.7\%). Of this above half of the participants were aged over 40 years with mean (SD) of 42.55 \pm 14.92 years. Concerning the sex of respondents, males accounted for $661(51.7 \%)$ and the majority $(319,74.7 \%)$ came from rural areas. Regarding levels of education, more than half (53.4\%) had no formal education (Table 2).

\section{Frequency of Visiting the Hot Springs, Duration of Use and Reason for Visiting}

Patients were visiting the hot spring sites yearly in 155 (36.3\%) of cases while, $136(32 \%)$ had visited for the first time. One hundred and eighty-six (43.6\%) of the patients
Table 2 Sociodemographic Characteristics of Patients Who Used Balneotherapy in Southern Ethiopia, 2019

\begin{tabular}{|c|c|c|c|}
\hline Variables & Categories & Frequency & Percent \\
\hline Age & $\begin{array}{l}<30 \text { years } \\
30-39 \text { years } \\
40-49 \text { years } \\
50-59 \text { years } \\
\geq 60 \text { year } \\
s\end{array}$ & $\begin{array}{l}92 \\
114 \\
84 \\
67 \\
70\end{array}$ & $\begin{array}{l}21.5 \\
26.7 \\
19.7 \\
15.7 \\
16.4\end{array}$ \\
\hline $\begin{array}{l}\text { Sex of } \\
\text { respondents }\end{array}$ & $\begin{array}{l}\text { Male } \\
\text { Female }\end{array}$ & $\begin{array}{l}196 \\
231\end{array}$ & $\begin{array}{l}46 \\
54\end{array}$ \\
\hline $\begin{array}{l}\text { Place of } \\
\text { residence }\end{array}$ & $\begin{array}{l}\text { Rural } \\
\text { Urban }\end{array}$ & $\begin{array}{l}319 \\
108\end{array}$ & $\begin{array}{l}74.7 \\
25.3\end{array}$ \\
\hline Religion & $\begin{array}{l}\text { Protestant } \\
\text { Muslim } \\
\text { Orthodox } \\
\text { Others }\end{array}$ & $\begin{array}{l}252 \\
121 \\
49 \\
5\end{array}$ & $\begin{array}{l}59.0 \\
28.3 \\
11.5 \\
1.2\end{array}$ \\
\hline Marital status & $\begin{array}{l}\text { Married } \\
\text { Single } \\
\text { Widowed } \\
\text { Divorced }\end{array}$ & $\begin{array}{l}367 \\
30 \\
27 \\
3\end{array}$ & $\begin{array}{l}85.9 \\
7.0 \\
6.3 \\
0.7\end{array}$ \\
\hline $\begin{array}{l}\text { Educational } \\
\text { levels }\end{array}$ & $\begin{array}{l}\text { Unable to read and } \\
\text { write } \\
\text { Read and write only } \\
\text { Grade I-8 (primary } \\
\text { education) } \\
\text { Grade 9-12 } \\
\text { (secondary education) } \\
\text { College, university }\end{array}$ & $\begin{array}{l}165 \\
63 \\
141 \\
42 \\
16\end{array}$ & $\begin{array}{l}38.6 \\
14.8 \\
33.0 \\
9.8 \\
3.7\end{array}$ \\
\hline Occupation & $\begin{array}{l}\text { Farmer } \\
\text { Housewife } \\
\text { Merchant } \\
\text { Daily laborer } \\
\text { Government/NGO } \\
\text { employee } \\
\text { Student } \\
\text { Others }\end{array}$ & $\begin{array}{l}164 \\
152 \\
43 \\
25 \\
18 \\
14 \\
11\end{array}$ & $\begin{array}{l}38.4 \\
35.6 \\
10.1 \\
5.9 \\
4.2 \\
\\
3.3 \\
2.5\end{array}$ \\
\hline $\begin{array}{l}\text { Average } \\
\text { monthly } \\
\text { income }\end{array}$ & $\begin{array}{l}<1000 \\
1000-2000 \\
2001-3000 \\
3001-5000 \\
>5000\end{array}$ & $\begin{array}{l}141 \\
73 \\
58 \\
54 \\
101\end{array}$ & $\begin{array}{l}33.0 \\
17.1 \\
13.6 \\
12.6 \\
23.7\end{array}$ \\
\hline Study site & $\begin{array}{l}\text { Burkitu (Hawassa) } \\
\text { Wondogenet } \\
\text { (Shebele) } \\
\text { Yirgalem (Yirgalem) } \\
\text { Barsiso (Dilla) }\end{array}$ & $\begin{array}{l}86 \\
116 \\
80 \\
145\end{array}$ & $\begin{array}{l}20.1 \\
27.2 \\
\\
18.7 \\
34.0\end{array}$ \\
\hline
\end{tabular}


were self-referred, 155 (36.3\%) previous users, 84 (19.7\%) referred by relatives or friends while, the remaining two $(0.5 \%)$ by traditional healers. More than two-third s $(69.6 \%)$ of the patients used the BT for three to five days (Table 3 ).

\section{LBP, Neurologic and Other Systemic Complaints of Patients Who Used BT}

Patients were asked whether they had associated symptoms and signs with back pain and responded as summarized in Table 4. To mention some, nearly a third had tenderness in back joint, about one-fifth had back pain with joint stiffness, and about a quarter had weaknesses of the extremities.

\section{Improvement Status of the Patients After Using Balneotherapy}

Of the total study participants who used balneotherapy 332 (77.8\%) with $95 \% \mathrm{CI}$ of $74-82 \%$ said they were completely relieved from back pain, while $95(22.2 \%)$ of the patients had no change in pain level. Among those with improved pain half $(50.5 \%)$ happened after two days of use, $123(37 \%)$ after three days of use and the rest 43 (12.5\%) after four or more days of balneotherapy use (Table 5).

\section{Bivariate Analysis of Factors Associated with Improvement from LBP After BT Use}

We assessed for association between sociodemographic and other factors with perceived improvement from low back pain among participants. Variables entered were site of hot springs, age, sex, place of residence, and presence of neurological symptoms. Hence, site of hot spring, sex of participants and having neurological symptoms were associated with perceived improvements. For example, the study site near Hawassa (Burkitu) shows an improvement from back pain with COR of 3.3 and $95 \%$ CI of $1.83-5.98$ and $p$-value $<0.001$. Another factor showing association in bivariate analysis was sex of respondents that the odds of perceived improvements among males was about twofold compared with females, (COR: 1.7, 95\%CI: 1.07-2.74, $\mathrm{p}$-value $=0.025$ ). Finally, improvement from back pain having associated symptoms like numbness/tingling paresthesia was nearly twice (COR: 1.92, 95\%CI:1.19-3.09, $p$-value $<0.01$ ) (Table 6)
Table 3 Frequency and Reasons for Visits and Duration of Stay Among Patients Who Use Balneotherapy in Southern Ethiopia 2019

\begin{tabular}{|l|l|l|l|}
\hline Variables & Categories & Frequency & Percent \\
\hline Frequency of visit & Daily & 68 & 15.9 \\
& Weekly & 44 & 10.3 \\
& Monthly & 24 & 5.6 \\
& Yearly & 155 & 36.3 \\
& For the first & 136 & 31.9 \\
& time & & \\
\hline For how long did you & 2 days & 85 & 19.9 \\
use balneotherapy? & $3-5$ days & 297 & 69.6 \\
& $>5$ days & 45 & 10.5 \\
\hline How did you come & I myself & 186 & 43.6 \\
here/visited here? & $\begin{array}{l}\text { Previous user } \\
\text { Family/friends/ } \\
\text { neighbors }\end{array}$ & 155 & 36.3 \\
& $\begin{array}{l}\text { Others } \\
\text { (traditional } \\
\text { healers) }\end{array}$ & 2 & 19.7 \\
\hline
\end{tabular}

\section{Discussion}

Our study assessed therapeutic properties and perceived improvement from lower back pain among adults using hot springs in Southern Ethiopia. Participants were asked about their pain condition at the initiation of bathing in the hot springs and followed for at least three days as per their

Table 4 Back Pain, Neurologic, and Systemic Health Problems Among Patients Who Complain of Back Pain of Balneotherapy Users at Southern Ethiopia, 2019

\begin{tabular}{|l|l|l|l|}
\hline Variables & Categories & Frequency & Percent \\
\hline $\begin{array}{l}\text { Have tenderness in the } \\
\text { back joint }\end{array}$ & Yes & 124 & 29.0 \\
\hline $\begin{array}{l}\text { Back pain with joint } \\
\text { stiffness }\end{array}$ & Yes & 303 & 71.0 \\
\hline Swelling around the joint & Yes & 20 & 17.8 \\
& No & 407 & 82.2 \\
\hline $\begin{array}{l}\text { Have numbness/tingling } \\
\text { paresthesia in the } \\
\text { extremities }\end{array}$ & Yes & 196 & 45.7 \\
\hline $\begin{array}{l}\text { Nave weakness of } \\
\text { extremities }\end{array}$ & Yes & 231 & 46.0 \\
\hline $\begin{array}{l}\text { Any of systemic health } \\
\text { problem, fever? }\end{array}$ & Yes & 107 & 54.0 \\
\hline No & 320 & 75.0 \\
\hline Have headache? & Yes & 220 & 30.7 \\
& No & 207 & 69.3 \\
\hline
\end{tabular}


Table 5 Therapeutics Effects of Hot Bath Among Patients Who Used Balneotherapy in Southern Ethiopia, 2019

\begin{tabular}{|l|l|l|l|}
\hline Variables & Categories & Frequency & Percent \\
\hline $\begin{array}{l}\text { Relief from back pain } \\
\text { after balneotherapy } \\
\text { use }\end{array}$ & $\begin{array}{l}\text { Yes } \\
\text { No }\end{array}$ & $\begin{array}{l}332 \\
95\end{array}$ & $\begin{array}{l}77.8 \\
22.2\end{array}$ \\
\hline $\begin{array}{l}\text { After how many days } \\
\text { you felt relief? ( } \mathrm{n}=332)\end{array}$ & $\begin{array}{l}\text { After two days } \\
\text { of use }\end{array}$ & 168 & 50.5 \\
\cline { 2 - 4 } & $\begin{array}{l}\text { After three } \\
\text { days of use }\end{array}$ & 123 & 36.9 \\
\cline { 2 - 4 } & $\begin{array}{l}\text { After four or } \\
\text { more days of } \\
\text { use }\end{array}$ & 43 & 12.6 \\
\hline
\end{tabular}

willingness to stay and again asked their pain condition at the end of balneotherapy use. Accordingly, the majority (three-quarters) of the patients reported improvement from lower back pain after immersion in spa waters and this perceived relief from pain was as early as two days among half of the participants.

This finding is in line with the several systematic reviews on balneotherapy in medicine citing the beneficial effects of balneotherapy on several diseases and conditions. $^{22,28,29}$ And also, as per an RCT, a single blind study on effectiveness of balneotherapy in chronic lower back pain, balneotherapy in itself can alleviate low back pain. ${ }^{29}$ Another similar study conducted in Hungary among elderly patients using balneotherapy shows that all monitored parameters of osteoarthritis of the knee joint and CLBP shows improvement from baseline after $\mathrm{BT}^{30}$ However, these studies did not report the levels of improvement and we have not identified any study that has reported the magnitude of CLBP improvements to compare with, and therefore, we suggest a national based survey to estimate the pattern and levels of balneotherapy use and perceived improvements from the pain.

Table 6 Bivariate Analysis of Factors Associated with Improvement from Back Pain After Balneotherapy Use

\begin{tabular}{|c|c|c|c|c|}
\hline \multirow[t]{3}{*}{ Variables } & \multicolumn{2}{|c|}{ Perceived Relief from CLBP } & \multirow[t]{3}{*}{ COR $(95 \% \mathrm{Cl})$} & \multirow[t]{3}{*}{$p$-value } \\
\hline & Yes & No & & \\
\hline & n (\%) & n (\%) & & \\
\hline \multicolumn{3}{|c|}{ Study site (hot springs) } & & $<0.001$ \\
\hline Burkitu (Hawassa) & $48(55.8)$ & $38(44.2)$ & $3.31(1.83-5.98)$ & 0.000 \\
\hline Bele (Wondogenet) & $99(85.3)$ & $17(14.7)$ & $0.72(0.37-1.39)$ & 0.32 \\
\hline Yirgalem & $68(85)$ & $12(15)$ & $0.74(0.35-1.54)$ & 0.41 \\
\hline Barsiso (Dilla) & II (88.7) & $28(19.3)$ & 1.00 & \\
\hline \multicolumn{3}{|l|}{ Sex } & & 0.025 \\
\hline Male & $162(82.7)$ & $34(17.3)$ & $\mathrm{I} .7(1.07-2.74)$ & \\
\hline Female & $170(73.6)$ & 61 (26.4) & 1.00 & \\
\hline \multicolumn{3}{|l|}{ Place of residence } & & 0.598 \\
\hline Urban & $82(76)$ & $62(24)$ & $0.87(0.52-1.45)$ & \\
\hline Rural & $250(78.4)$ & $69(21.6)$ & 1.00 & \\
\hline \multicolumn{3}{|l|}{ Age categories } & & 0.16 \\
\hline$<30$ years & $74(80.4)$ & $18(19.6)$ & 1.00 & \\
\hline $30-39$ years & $79(69.3)$ & $35(30.7)$ & $1.82(0.95-3.49)$ & 0.07 \\
\hline $40-49$ years & $67(79.8)$ & $17(20.2)$ & $1.04(0.49-2.19)$ & 0.91 \\
\hline $50-59$ years & $55(82)$ & $12(18)$ & $0.89(0.99-2.01)$ & 0.79 \\
\hline$\geq 60$ years & $57(81.4)$ & $13(18.6)$ & $0.94(0.42-2.07)$ & 0.87 \\
\hline \multicolumn{2}{|c|}{ Have numbness/tingling/paresthesia } & & & 0.007 \\
\hline Yes & $164(49.4)$ & $32(33.7)$ & $1.92(1.19-3.09)$ & \\
\hline No & $168(50.6)$ & $63(66.3)$ & 1.00 & \\
\hline
\end{tabular}


In addition, studies from Germany and Finland revealed that on top of reducing pain, hydrotherapy can be used to specifically improve, strength and/or prevent muscle wastage; posture, flexibility and/or prevention of contracture (shortening and hardening of muscles, tendons or other tissue); ability to perform normal everyday activities, including walking; exercise and work tolerance; cardiovascular fitness and balance and reaction times. ${ }^{31}$ However, improvements in the symptoms of LBP, decreasing stress level and feeling well might have a positive effect on the psychological status of patient with LBP. Furthermore, this psychological improvement might lead to success in patients' social life.

There is also encouraging evidence suggesting that balneotherapy may be effective for treating patients with LBP. For example, the data from systematic reviews and meta-analysis suggest significant differential effects in favor of balneotherapy for reducing low back pain. ${ }^{32,33}$

Another study on short term efficacy of balneotherapy among CLBP patients indicates balneotherapy was found to produce minimal pain, improved functionality, and quality of life and reduce fatigue and disability status. ${ }^{34}$ According to the results of the Naiade Project, balneotherapy significantly reduces the need for other types of treatment (hospitalization, physical therapy, and pharmacotherapy). ${ }^{35}$ It was also reported by RCT on the effect of thermal water containing magnesium-calciumbicarbonate on CLBP therapy that balneotherapy was found to improve quality of life of patients suffering from CLBP. ${ }^{36}$

Our study revealed that about half of the participants have shown improvement from CLBP within two days of BT use. However, this is quite different from previous studies that have reported longer (more days) to show improvement. For example, studies have reported low back pain lasts longer than 12 weeks without improvement, at which point it is considered chronic; levels of pain and disability often remain relatively constant thereafter. ${ }^{4}$ Another study by Constant et al, revealed three weeks duration to show improvement from CLBP. $^{37}$ This discrepancy may be that our study did not include a comparison group and considered respondents subjective report of relief from back pain. Another possible reason for the shortest time reported in our study would be that the physicochemical analysis of the study hot springs shows high temperature that ranges from $42.8^{-}$ $60.2^{\circ} \mathrm{C}$ and high levels of other minerals.
The current study showed that perceived improvement from lower back pain after BT is associated with male sex, having concomitant neurological symptoms and being using hottest $\left(60.2 \mathrm{C}^{\circ}\right)$ spring waters and increased $\mathrm{SO}_{4}{ }^{2-}$ sulphate and other minerals content. This study specifically assessed the association between various factors and perceived relief from pain using bivariate analysis and $p$-value. This evidence should be supported by a comparative group, which is one of the limitations of our study.

The findings of our study suggest the need for further study involving trials with double-blinded comparative groups and different treatment approaches to recommend the best alternative method, be the combination of methods as suggested by previous studies, ${ }^{4,22,29,30}$ or balneotherapy alone, to support patients with chronic lower back pain in Ethiopia. This is due to the fact that pharmacological therapy using nonsteroidal anti-inflammatory drugs may induce significant clinical side effects with meaningful clinical consequences. ${ }^{38}$ Moreover, the traditional use of hot spring water for various diseases including back pain is very common in almost all parts of Ethiopia, but little is known about its effectiveness and efforts to integrate it into modern medicine is poor. We, therefore, recommend all concerned bodies to pay more emphasis to further research and its uses to the national hot springs.

Our study is not free from limitations. As we have conducted a single-arm cohort study where only adults using balneotherapy by themselves were conveniently included in the study and followed only for three days, ascertainment of improvement could not be compared with control groups. Moreover, an assessment of improvement from CLBP was through perceived/subjective report by participants that we did not measure pain intensity score; ascertainment bias could be very likely. Also, due to patients preference it was assumed and as a trend most of the patients in all the studied hot springs stay for an average of three days at the site, we were unable to follow them for a longer period and this could hinder the recommended (two weeks) ${ }^{30}$ effect of balneotherapy for the treatment of CLBP.

\section{Conclusions}

The current study shows hot spring bathing for three or more days had significant effects of improvement among patients with lower back pain. The perceived relief from pain was as early as two days among half of the 
participants. The improvement is associated with type of hot spring used, male sex and having neurological symptoms. Therefore, hot spa spring water had better therapeutic effects for chronic lower back pain and therefore, emphasis should be given to integrating it with modern medicine and further experimental study to be conducted to recommend it for use for medical purposes.

\section{Abbreviations}

BT, Balneotherapy; CLBP, Chronic low back pain; LBP, Low back pain; EBM, Evidence Based Medicine; IRB, Institutional Review Board; RCT, Randomized Controlled Trial; SNNPR, Southern Nations Nationalities and Peoples' Region; RA, Rheumatoid arthritis; WHO, World Health Organizations.

\section{Data Sharing Statements}

The dataset regarding the current study will be shared upon request from the corresponding author.

\section{Ethical Issues}

The current study was conducted in accordance with Declaration of Helsinki. An ethical clearance was secured from the Institutional Review Board (IRB) of the College of Medicine and Health Sciences, Hawassa University. The data were collected after taking written consent from respondents. First, we described the purpose of the study and its benefits for the participants, and then, we conducted diagnosis for presence of CLBP after their permission. In addition, permission was taken from the hot spring owners.

\section{Acknowledgment}

We want to express our great thanks to Hawassa University, Research and Technology Transfer Directorate Office for the financial support. We would also like to thank all data collectors and supervisors for their cooperation to realize our objective by giving necessary data during the collection. Lastly, we are extremely grateful to those patients who participated in this study for their willingness to share their health status.

\section{Author Contributions}

All authors contributed to data analysis, drafting or revising the article, have agreed on the journal to which the article will be submitted, gave final approval of the version to be published, and agree to be accountable for all aspects of the work.

\section{Funding}

No funding received from funding agency but Hawassa University supported the study through paying for the research staffs.

\section{Disclosure}

The authors report no conflicts of interest in this work.

\section{References}

1. Felson DT. Epidemiology of the rheumatic diseases. In: Koopman W, editor. Arthritis \& Allied Conditions. Philadephia, PA: Lippincott, Williams \& Collens; 2000.

2. Chou R. Low back pain (chronic). In: American Academy of Family Physicians, editor. Clinical Evidence Handbook. BMJ Publishing Group; 2011: 403-405.

3. Manchikanti L. Epidemiology of low back pain. Pain Physician. 2000;3:167-192. doi:10.36076/ppj.2000/3/167

4. Gore M, Tai KS, Sadosky A, Leslie D, Stacey BR. Use and costs of prescription medications and alternative treatments in patients with osteoarthritis and chronic low back pain in community-based settings. Pain Pract. 2012;12:550-560. doi:10.1111/j.15332500.2012.00532.x

5. Monroe JS, Nathaniel R. Healing Springs: The Ultimate Guide to Taking the Waters from Hidden Springs to the World Greatest Spas. Healing Arts Press; 2000.

6. Sandison E. Health Resorts and Medicine: Medical Subject Index with Reference Bibliography. 1st ed. 1987.

7. Huang A, Seité S, Adar T. The use of balneotherapy in dermatology. Clin Dermatol. 2018;36(3):363-368. doi:10.1016/j.clindermatol.2018.03.010

8. Ranasinghe PN. The Source Of Hot Springs And Mahapelessa Hot Spring," Ruhunu tourist bureau. Galle, SL; 2005:1-16.

9. Bennett RM, Jones J, Turk DC, Russell IJ, Matallana L. An internet survey of 2596 people with fibromyalgia. BMC Musculoskelet Disord. 2007;8:27.

10. Routh HB, Bhowmik KR, Parish LC, Witkowski JA. Balneology, mineral water, and spas in historical perspective. Clin Dermatol. 1996;14:551-554. doi:10.1016/S0738-081X(96)00083-1

11. Food, Medicine and Healthcare Administration and Control Authority of Ethiopia. Standard Treatment Guidelines for General Hospital. 3rd ed. 2014.

12. Adler E. Some clinical experience with the springs at Zohar on the shore of the Dead sea. Isr J Med Sci. 1961;20:304-308.

13. Nguyen M, Revel M, Dougados M. Prolonged effects of 3 week therapy in a spa resort on lumbar spine, knee and hip osteoarthritis: follow-up after 6 months. A randomized controlled trial. $\mathrm{Br}$ J Rheumatol. 1997;36(1):77-81. doi:10.1093/rheumatology/36.1.77

14. Kovacs I, Bender T. The therapeutic effects of Cserkeszolo thermal water in osteoarthritis of the knee: a double blind, controlled, follow-up study. Rheumatol Int. 2002;21:218-221. doi:10.1007/ s00296-001-0167-6

15. Green J, Mckenna F, Redfern EJ, Chamberlain MA. Home exercises are as effective as outpatient hydrotherapy for osteoarthritis of the hip. Br J Rheumatol. 1993;32:812-815. doi:10.1093/rheumatology/ 32.9.812

16. Wigler I, Elkayam O, Paran D. Spa therapy for gonarthrosis: a prospective study. Rheumatol Int. 1995;15:65-68. doi:10.1007/ BF00262710

17. Bojadgieva K, Dipchikova S, Benderev A, Koseva J. Mineral Waters and Spa Tourism in Bulgaria. 2005. Available from: https://www.geothermal-energy.org/pdf/IGAstandard/ISS/ 2003Germany/I/4_1.kla.pdf. 
18. Angioni MM, Denotti A, Pinna S, et al. Spa therapy induces clinical improvement and protein changes in patients with chronic back pain. Reumatismo. 2019;71(3):119-131. doi:10.4081/reumatismo. 2019.1200

19. Ozkuk K, Dilekci E. The effects of balneotherapy in elderly patients with chronic low back pain treated with physical therapy: a pilot study. J Ist Faculty Med. 2019. doi:10.26650/IUITFD.2019.0025

20. Petya K, Anna M, Nikoleta T, Penka P. A study of the effect of the combined application of a physiotherapeutical program with therapeutic fit balls in cases of chronic pain in the lumbar area. Biomedical Res. 2019;30(2):238-240.

21. Alessio P, Roberto D, Alessandra M, et al. Thermal balneotherapy in Antsirabe-Madagascar: water analysis and its applications in an African context. Acta Biomed. 2016;87(Supplement 1):25-33.

22. Bai R, Li C, Xiao Y, Sharma M, Zhang F, Zhao Y. Effectiveness of spa therapy for patients with chronic low back pain. Medicine. 2019;98(e17092):37. doi:10.1097/MD.0000000000017092

23. Verhagen AP, Cardoso JR, Bierma-Zeinstra SMA, et al. Aquatic exercise \& balneotherapy in musculoskeletal conditions. Best Pract Res Clin Rheumatol. 2012;26:335-343. doi:10.1016/j. berh.2012.05.008

24. U.S. Department of Health and Human Services, National Institutes of Health (NIH). Back Pain. Office of Communications and Public Liaison National Institute of Neurological Disorders and Stroke, NIH; 2014: 15-5161. Available from: http://www.ninds.nih.gov. Accessed July 28, 2021.

25. APHA (American Public Health Association). Standard Methods for the Examination of Water and Wastewater". 20th ed. Washington, DC; 1998.

26. University of Michigan Health system (UMHS). Guideline for Clinical Care Ambulatory. Low Back Pain Guideline Update. 2010.

27. World Health Organization (WHO). Guidelines for Drinking Water Quality: Surveillance and Control of Communities Supplies. 2nd ed, Vol. 3. Geneva, Switzerland: WHO; 1997.

28. Tefner IK, Németh A, Lászlófi A, et al. The effect of spa therapy in chronic low back pain: a randomized controlled, single-blind, follow-up study. Rheumatol Int. 2012;32:3163-3169. doi:10.1007/ s00296-011-2145-y

29. Balogh Z, Ordögh J, Gász A, Német L, Bender T. Effectiveness of balneotherapy in chronic low back pain - a randomized single-blind controlled follow-up study. Forsch Komplementarmed Klass Naturheilkd. 2005;12(4):196-201. doi:10.1159/000086305
30. Gaál J, Varga J, Szekanecz Z, et al. Balneotherapy in elderly patients: effect on pain from degenerative knee and spine conditions and on quality of life. Isr Med Assoc J. 2008;10(5):365-369.

31. Bennett RM, Jones J, Turk DC, Russell IJ, Matallana L. An internet survey of 2596 people with fibromyalgia. BMC Musculoskelet Disord. 2007;8:27.

32. Roques CF, Queneau P. Médecines thermals et douleurs des lombalgies chroniques, gonarthrose ou fibromyalgia [SPA therapy for pain of patients with chronic low back pain, knee osteo-arthritis and fibromyalgia]. Bull Acad Natl Med. 2016;200(3):575-86; discussion 586-7.

33. Pittler MH, Karag"ulle MZ, Karaguulle M, Ernst E. Spa therapy and balneotherapy for treating low back pain: meta-analysis of randomized trials. Rheumatology (Oxford). 2006;45:880-884. doi:10.1093/ rheumatology/kel018

34. Dilekçi E, Özkuk K, Kaki B. The short-term effects of balneotherapy on pain, disability and fatigue in patients with chronic low back pain treated with physical therapy: a randomized controlled trial. Complement Ther Med. 2020;54:102550. doi:10.1016/j. ctim.2020.102550

35. Fioravanti A, Valenti M, Altobelli E, et al. Clinical efficacy and costeffectiveness evidence of spa therapy in osteoarthritis. The results of "Naiade" Italian Project. Panminerva Med. 2003;45(3):211-217.

36. Gáti T, Tefner IK, Kovács L, et al. The effects of the calcium-magnesium-bicarbonate content in thermal mineral water on chronic low back pain: a randomized, controlled follow-up study. Int J Biometeorol. 2018;62:897-905. doi:10.1007/s00484017-1491-1

37. Constant F, Collin JF, Guillemin F, et al. Effectiveness of spa therapy in chronic low back pain: a randomized clinical trial. J Rheumatol. 1995;22:1315-1320.

38. White AP, Arnold PM, Norvell DC, Ecker EBS, Fehlings MG. Pharmacologic Management of Chronic Low Back Pain. Spine. 2011;36:S131-S143. doi:10.1097/BRS.0b013e31822f178f
Journal of Pain Research

\section{Publish your work in this journal}

The Journal of Pain Research is an international, peer reviewed, open access, online journal that welcomes laboratory and clinical findings in the fields of pain research and the prevention and management of pain. Original research, reviews, symposium reports, hypothesis formation and commentaries are all considered for publication. The manuscript management system is completely online and includes a very quick and fair peer-review system, which is all easy to use. Visit http:// www.dovepress.com/testimonials.php to read real quotes from published authors. 